ELORE (ISSN 1456-3010), vol. 17 - 2/2010.

Julkaisija: Suomen Kansantietouden Tutkijain Seura ry.

[http://www.elore.fi/arkisto/2_10/hamalainen_2_10.pdf]

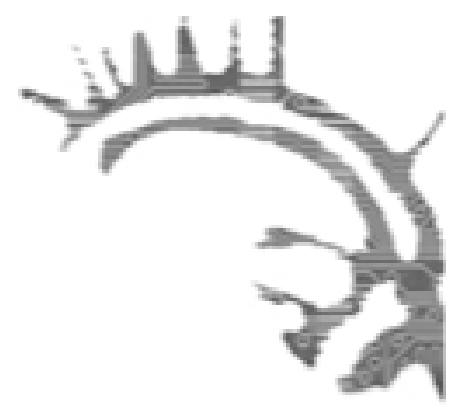

KiRJA-ARVIO

\title{
Leo Tolstoin ankarat AatTeEt SuOMEn KehitTrvässä KUlT- TUURISSA
}

TURTIAINEN, MINNA \& WAHLROOS, TUIJA (toim.) 2010: Maaemon lapset. Tolstoilaisuus kulttuurihistoriallisena ilmiönä Suomessa. Suomalaisen Kirjallisuuden Seuran Toimituksia 1260, Tieto. Helsinki: SKS. 192 sivua.

$\underline{\text { Tommi-Tapio Hämäläinen }}$

Venäjän kansalliskirjailija Leo (Lev Nikolajevitš) Tolstoi (1828-1910) muistetaan ehkä tavallisimmin teoksistaan Sota ja rauha (1865-1869) sekä Anna Karenina (1875-1877). Tolstoin romaanit ovat maailmankirjallisuuden klassikoita, jotka herättävät aikojen saatossa yhä uusia tulkintoja. Esimerkiksi Anna Kareninasta on julkaistu 1900-luvun kuluessa kolme suomennosta. Kirjan pohjalta on tehty yhteensä toistakymmentä elokuvaa ja tv-sarjaa sekä lukuisia teatteridramatisointeja. Tolstoin realistinen tapahtumakuvaus ja symbolistinen kirjoitustyyli ovat myös toimineet esikuvina lukuisille uusille kirjailijoille nykyaikaan asti.

Kulttuurihistoriaan perehtyneet tuntevat Tolstoin myös yhteiskuntakriitikkona, jonka näkemykset herättivät omana aikanaan suurta kohua. Tolstoin kantaaottavia tekstejä pidettiin tsaarin ajan Venäjällä jopa siinä määrin anarkistisina, että sensuuri kielsi useita hänen julkaisuistaan. Niitä levitettiin salaa, käännettiin ja painettiin ulkomailla, kuten Ruotsissa. Tolstoin teokset herättivät 1800-1900-lukujen vaihteessa keskustelua ympäri Eurooppaa ja Amerikkaa. Leo Tolstoi ilmaisi usein suoraan olevansa sitä mieltä, että yhteiskunnalliset ongelmat olivat seurausta tulojen epätasaisesta jakautumisesta. Hän vastusti kirkkoa, vallanpitäjiä ja yläluokan elämäntapaa. Hänen näkemyksensä oli, että ratkaisu ongelmiin löytyisi kristillisiä oppeja soveltavasta kommuunielämästä. Tolstoi kritisoi ankarasti myös oman aikansa elitististä kuvataidetta ja taideinstituutioita. 
Tommi-Tapio Hämäläinen: Leo Tolstoin ankarat aatteet Suomen kehittyvässä kulttuurissa

\section{YKSITOISTA NÄKÖKULMAA TOLSTOILAISUUTEEN}

Tolstoin yhteiskunnallinen toiminta ja tinkimättömät eettiset periaatteet ovat pääosassa Minna Turtiaisen ja Tuija Wahlroosin toimittamassa Maaemon lapset -teoksessa. Kirja koostuu yhdestätoista artikkelista, joissa tarkastellaan, miten Tolstoin ajatukset vaikuttivat Suomen kulttuurielämään 1800-luvun lopulla ja 1900-luvun alkupuolella. Kirjoitukset valottavat toisiaan täydentävästi Tolstoin aatteiden keskeisiä piirteitä ja vaikutuksia Suomen yhteiskuntaelämään sekä taiteeseen.

Galina Aleksejeva tarkastelee artikkelissaan Tolstoin suhdetta yhteisöliikkeisiin. Nina Kokkinen valaisee, miten tolstoilaisuus sopi teosofian kannattajien tulkintoihin. Pertti Karkama tarkastelee tolstoilaisuuden ilmentymiä suomalaisessa kulttuurielämässä. Ben Hellman ja Tamara Burlakova kartoittavat omissa kirjoituksissaan yksityiskohtaisesti Tolstoin ja suomalaisten välistä yhteydenpitoa. Maija SaloniusHatakka kertoo enojensa, Akseli ja Eelo Isohiiden tolstoilaisesta elämästä. Mervi Tuomikoski pohtii Arvid Järnefeltin suhdetta Tolstoin taidekäsitykseen ja Venäjän symbolistiseen kirjallisuustraditioon. Riitta Konttinen puolestaan arvioi tolstoilaisuuden ilmenemistä suomalaisessa kuvataiteessa. Anna-Maria von Bonsdorff, Ritva Kava sekä Tuija Wahlroos selvittävät kukin omissa artikkeleissaan eri taiteilijoiden suhteita Tolstoihin ja tämän aatteisiin. Teos on loppupuoleltaan kuvataiteeseen painottuva, sillä se on toimitettu julkaistavaksi Gallen-Kallelan Museon samannimisen näyttelyn yhteydessä (5.6.-29.8.2010). Kirja ja näyttely on tehty toisiaan täydentäviksi mutta samalla itsenäisiksi kokonaisuuksiksi.

Maaemon lapset -kirja onkin monipuolisen sisältönsä ansiosta paljon enemmän kuin pelkkä näyttelyn oheisjulkaisu. Useista asiantuntija-artikkeleista koostuvaa kirjaa voidaan hyödyntää oivallisesti niin kulttuurihistoriallisena, aatehistoriallisena kuin taidehistoriallisena lähdeteoksena. Teos sisältää näytteitä ja tietoa sekä kirjallisuudesta että kuvataiteesta. Koska Maaemon lapset koostuu suuresta joukosta erillisiä kirjoituksia, tarkastelen sen sisältöjä seuraavassa rajatusti, muutamien valikoitujen poimintojen kautta.

\section{UTOPIAA ETSIMÄSSÄ}

Galina Aleksejeva tarkastelee artikkelissaan Tolstoin suhdetta yhteisöliikkeisiin, jotka olivat kirjailijalle hyvin läheinen aihe. Leo Tolstoi sekä tutki eri yhteisöteoreetikkojen ajatuksia, tutustui käytännön yhteisöihin, sekä toimi oppi-isänä monille yhteisöjen perustajille. Tolstoin yhteisöihanteiden lähtökohtana oli hänen oma eettinen maailmankatsomuksensa. Hän uskoi kristillisen opin järkeistettyyn tulkintaan: uskontoa tuli toteuttaa jokapäiväisessä elämässä. Ihminen ei saanut harjoittaa väkivaltaa, ei elää toisten työstä eikä sukupuolivietti saanut hallita häntä. Vaatetuksen tuli olla yksinkertainen, ravinnon piti koostua kasviksista ja kaikenlaisia nautintoaineita oli vältettävä. Tolstoin mukaan päivään kuului neljä osaa: ruumiillista työtä, käsitöitä, seurustelu ja henkisten töiden aika. Hänen näkemyksensä oli, että tällainen elämän- 
tapa saattoi toteutua hedelmällisimmin muusta yhteiskunnasta erillään asuvassa yhteisössä - siirtokunnassa, kommuunissa. Aleksejeva kertoo, miten Tolstoi toi ideansa yhteisomistukseen perustuvasta elämästä ilmi myös romaaneissaan. Hän kehitteli aihetta muun muassa Anna Kareninassa, Konstantin Levinin vuoropuhelussa Nikolai-veljensä kanssa.

Tolstoi löysi myös yhteisöteorioista kiinnostuneita aateveljiä, joiden kanssa hän kävi kirjeenvaihtoa ympäri Eurooppaa. Aleksejeva esittelee kirjoituksessaan, miten Tolstoin ajatukset saivat seuraajia ja synnyttivät yhteisöjä useissa eri maissa. Muun muassa Englannissa kehittyi voimakkaita yhteisöliikkeitä, jotka nousivat älylliseksi protestiksi viktoriaanista moraalia vastaan. Eräs näistä oli kasvissyöntiä puolustavan Henry S. Saltin (1851-1939) liike Humanitarian League. Salt vastusti erityisesti metsästystä. Hänet tunnetaan nykyisin eläinten oikeuksia ajavien liikkeiden pioneerina. Aleksejevan mukaan Salt tukeutui toiminnassaan Tolstoin teoksiin, joissa tämä kannustaa väkivallattomuuteen ja kasvissyöntiin. Tolstoi itse puolestaan julkaisi Posrednik-kustantamossaan vuonna 1896 venäjännöksen Saltin teoksesta Humanitarian teaching or humanitarianism. Tolstoista tuli myös useiden vaihtoehtoista elämäntapaa harjoittavien yhteisöjen innoittaja. Esimerkiksi English New Life -liikkeen edustajat seurasivat tämän aatteita muuttamalla maalle, lähelle luontoa, elämään oman fyysisen työnsä ja viljelystensä antimista.

Artikkelin kirjoittaja kertoo, kuinka Tolstoi kiinnostui vuosina 1880-1890 varsinkin amerikkalaisista ihanneyhteisöistä, jotka perustuivat kristilliseen elämään mutta jäivät lähes pääsääntöisesti väliaikaisiksi kokeiluiksi. Hän ymmärsi myös kommuunien taipumuksen rappeutua, koska ne koostuivat inhimillisistä jäsenistä. Tolstoi tiedosti, että ihanneyhteiskunta saattoi olla saavuttamaton päämäärä, utopia - mutta ei halunnut antaa tämän pysäyttää sen tavoittelemista.

\section{TolstoilaisuUs JA AJAN MUUT AATTEET}

Kirjan artikkelit täydentävät ja laajentavat toisiaan hedelmällisellä tavalla. Aleksejevan jälkeen Nina Kokkinen kirjoittaa omassa tekstissään suomalaisten teosofien yhteyksistä Tolstoin oppeihin. Kokkinen kertoo, että Suomen tunnetuin teosofi Pekka Ervast (1875-1934) luki paljon Tolstoita ja tulkitsi tämän ajatuksia myös omissa esitelmissään. Vaikka teosofien maailmankuva poikkesi merkittävällä tavalla Tolstoin kristillisyydestä, Ervast näki myös yhtäläisyyksiä oppien välillä. Vahvin yhtäläisyys löytyi kritiikistä kirkkoa ja papiston opillista valtaa kohtaan. Merkittävin eroavaisuus oli, että Raamattu oli teosofeille vain yksi salattua tietoa sisältävä kirja monien joukossa. Kokkinen esittää, että Tolstoin kannalta olikin hieman ironista, että teosofit ulottivat eklektisen lukutapansa myös tämän kirjoihin: he erottelivat näistäkin itselleen sopivat salatun viisauden jyvät. Kaikki ylimääräiseksi koettu karsittiin pois - vaikka kyseessä olisivat olleet juuri ne opit, joita Tolstoi alleviivasi ydinajatuksinaan. 
Pertti Karkama puolestaan tarkastelee tolstoilaisuutta suomalaisessa kulttuurielämässä, 1800- ja 1900-luvun vaihteen aatteellisten virtausten kuohunnassa. Myös hän kiinnittää huomionsa siihen, että Tolstoin opilliset ajatukset saivat aikansa suomennoksissa ja näiden jatkotulkinnoissa eri merkityksiä kuin alkuteksteissä ja niiden venäläisessä luennassa. Karkama esittää, että Tolstoi kansallistettiin suomalaisessa luennassa. Tolstoin oman käsityksen mukaan ihmiset olivat historiallisen ajan uhreja, jotka vain koettivat turhaan ponnistella sen kulun ohjaamiseksi. Hän näki, että ratkaisu kahleista irtautumiseen oli löydettävissä siten, että alettaisiin elää päivä kerrallaan ja pyrittäisiin elämään omaa arkea kristillisten perusperiaatteiden mukaisesti. Tolstoin ajatuksia välitti maahamme muun muassa Arvid Järnefelt (1861-1932). Karkama tarkastelee, miten Järnefelt toi tolstoilaisuutta esiin omassa kirjallisuudessaan ja yhteiskunnallisessa toiminnassaan. Koska Tolstoi esiintyi usein varsinkin maaseudun työväestön puolestapuhujana, Järnefelt sovelsi tämän tekstejä myös puolustaessaan torpparien oikeuksia itse muokkaamaansa maahan. Snellmanilaiset aktivistit ottivat nämä näkemykset mielellään omakseen ja Tolstoin aatteet ideologisoitiin kansallisten poliittisten pyrkimysten palvelukseen. Karkama kertoo, että Järnefelt pyrki kuitenkin itse ensisijaisesti välittämään Tolstoin ajatuksia suomalaisille alkuperäistekstien käännöksissä ja omassa kirjallisuudessaan. Järnefeltiä jopa kritisoitiin siitä, että hän seurasi teoksissaan liian tunnollisesti Tolstoin periaatteita ja kirjallisen kerronnan malleja.

Maaemon lapset -teoksen seuraavissa kolmessa artikkelissa esitellään ja tarkastellaan Tolstoin Suomeen liittyviä kirjallisia aineistoja, kuten käsikirjoituksia ja kirjeenvaihtoa. Niissä kuvataan myös suomalaisten henkilökohtaisia vierailuja kirjailijan luona sekä Suomen varsinaisten niin sanottujen tolstoilaisten käytännön elämää. Empiiriseen tarkasteluun perustuvat jaksot täydentävät hyvin kirjan teoreettis-pohdinnallisia tekstejä. Runsaat aineistonäytteet ja tapauskuvaukset havainnollistavat oivallisesti, miten Tolstoin aatteet ja häntä kohtaan koettu ihailu ilmenivät käytännössä. Toisessa Arvid Järnefeltiin keskittyvässä tutkielmassa Mervi Tuomikoski analysoi syventävästi, millaista kirjeenvaihtoa tämä kävi Tolstoin kanssa kirjoittaessaan omia teoksiaan ja miten Järnefelt sovelsi työssään Tolstoin aatteita sekä venäläisen symbolismin perinteitä.

\section{MAAEMON LAPSET TuUSUlanjäRVEN RANNALLA}

Kirjan loppuosassa tarkastellaan Tolstoin vaikutuksia suomalaiseen taiteeseen ja maamme taiteilijoiden elämään. Lähtökohta ei perustu ainoastaan siihen, että $M a a-$ emon lapset on julkaistu samannimisen kuvataidenäyttelyn yhteydessä. Tälle painotukselle on myös selkeät historialliset perusteet: Tolstoin ajatukset vaikuttivat suomalaiseen kulttuurielämään varsinkin helsinkiläisten taiteilijoiden yllä pitämien Ullanlinnan ja Tuusulan yhteisöjen välityksellä. Useat maamme keskeisistä kulttuurivaikuttajista olivat jatkuvasti tiiviissä kanssakäymisessä keskenään ja tolstoilaisuus levisi seurapiireissä. Järnefeltin veljesten lisäksi muun muassa Pekka Halonen (1865- 
Tommi-Tapio Hämäläinen: Leo Tolstoin ankarat aatteet Suomen kehittyvässä kulttuurissa

1933), Venny Soldan-Brofeldt (1863-1945) ja Aino Sibelius (1871-1969) - omaa sukuaan Järnefelt - vaikuttuivat aatteista. Teoksessa esitellään taiteilijoiden aatteellista kanssakäymistä sekä useita teoksia, joissa voidaan nähdä tolstoilaisia sävyjä.

Maaemon lapset -teoksen merkittävin anti on, että kirja kokoaa yksiin kansiin suuren joukon tuoreita, eri näkökulmista tehtyjä tutkimuksia Tolstoin elämästä, aatteista ja kulttuuriyhteyksistä. Tolstoita on toki tutkittu aikojen saatossa runsaasti eri näkökulmista, mutta näiden tarkastelujen moninaiset tiedot ja tulkinnat ovat hajallaan useissa eri julkaisuissa. Vaikka Tolstoi on varsinkin kirjallisuuden historiassa huomattavan tunnettu henkilö, aiempi kattava tutkimus hänen vaikutuksistaan Suomen kulttuurielämään on tehty viimeksi 1950-luvulla (ks. Nokkala 1958).

Maaemon lapset sisältää monipuolisten artikkelien lisäksi huomattavan runsaasti mielenkiintoista kuva-aineistoa. Kuvitus koostuu historiallisista valokuvista, käsikirjoitusotteista, kirjeistä ja kuvataiteilijoiden teoksista. Kuvituksessa hyödynnetyt maalaukset kertovat omalla visuaalisella kielellään, miten Tolstoin aatteet ja ihanteet näkyvät suomalaisessa kulttuurikuvastossa 1800-1900-lukujen vaihteessa.

KirjallisuUs

NOKKALA, ARMO 1958: Tolstoilaisuus Suomessa. Aatehistoriallinen tutkimus. Helsinki: Tammi

Filosofian maisteri Tommi-Tapio Hämäläinen on folkloristiikan jatko-opiskelija Helsingin yliopiston Filosofian, kulttuurin ja taiteen tutkimuksen laitoksella. 